\title{
Impact of Public-Private Partnership on Water Service Delivery in Kenya
}

\author{
Joseph Okeyo Obosi \\ Department of Political Science \& Public Administration, University of Nairobi, Nairobi, Kenya \\ Email: jobosi@uonbi.ac.ke, jokeyoobosi@gmail.com
}

How to cite this paper: Obosi, J. O. (2017). Impact of Public-Private Partnership on Water Service Delivery in Kenya. Open Journal of Political Science, 7, 211-228. https://doi.org/10.4236/ojps.2017.72017

Received: January 17, 2017

Accepted: April 10, 2017

Published: April 13, 2017

Copyright (C) 2017 by author and Scientific Research Publishing Inc. This work is licensed under the Creative Commons Attribution International License (CC BY 4.0).

http://creativecommons.org/licenses/by/4.0/

\begin{abstract}
Public-private partnership has increasingly become a preferred public service delivery approach in the provision of water services in Kenya. As a strategy, PPP in water service provision was started in Kenya following water sector reforms as contained in the Water Act 2002. In order to establish the impact of PPP on water service delivery in Kenya, a household survey of 288 respondents from seven (7) Water Service Providers (WSPs) comprising four Water Utility companies and three Community Water projects, under the Lake Victoria South Water Services Board (LVSWSB) umbrella was conducted. Using quantitative techniques to analyze the data under governance theory, the study established that compared to the period up to 2004, the households experienced better services in the year 2012 in terms of water quality, affordability, access and customer service levels as currently observed compared to the period up to 2004 to the extent that public institutions that had adopted more private sector participation performed better than those that have not. On average, there was reduction in: distance to water point reduced by 78.3 $\mathrm{m}$; frequency of coloured water by 0.2 days, time taken to restore water 3 days within the ten years period.
\end{abstract}

\section{Keywords}

Public Private Partnership, Water, Reforms, Policy, Service Delivery

\section{Introduction}

A Public Private Partnership (PPP) arrangement refers to cooperation between the public and private sectors in providing public goods. The functioning principles of private enterprise are in cooperation in public administration with a view to improving the quality and efficiency of public service delivery (Tochitskaya, 2007). An emerging consensus is that the state was overextended, inefficient and needed to roll back from economic ventures in order to concentrate on 
activities it could do best, essentially, provision of enabling environment for the provision of public goods by either the private sector or a combination of both. At the same time, the state recognized the need to relate the social and economic goals set in light of a consideration that the private sector has comparative advantage in delivery of certain services which when put to good use, would facilitate the achievement of these goals (Hulme, 1992). Partnerships have therefore been seen as effective means of implementing public policies and a means of developing socially inclusive communities (Osborne, 2000). The pressure to maintain certain levels of public service, and financial constraints placed on public service delivery compelled governments to look for alternative mechanisms for service provision, hence the Public-Private Partnerships. PPPs enabled private sector, not for profit organizations, and community organizations to play roles, not just in the common practice of implementation but also to have authoritative voice in public policy making. It does not mean that public private partnerships have been successful in improving water service delivery in all instances. There have been mixed results from public private sector participation in water supply although there have been more gains than drawbacks (Prasad, 2006). Whereas, there was increased access to water under PPP in Congo Brazzaville (Tati, 2005) and related positive results in Uganda (Schwartz, 2008), in Zambia, privatization resulted into reduced access and increased cost of water and the utilities had to be returned to public management (Dagdeviren, 2008).

The Government of Kenya allowed private sector participation on a large scale in water sector from the year 2003 as a means of enhancing access to safe water following the enactment of Water Act 2002 (K'akumu, 2004). It engaged in a systematic commercialization of water departments by injecting private sector management by forming Eight Water Service Boards (WSB). Before then, the Government of Kenya used the public sector to provide water services through the Ministries of Water Development to develop and oversee the country's water resources and Local Government to provide water services especially in urban areas (K'Akumu, 2007). Under the public sector management, water service provision in Kenya faced a number of persistent problems in water supply and management: frequent water shortages and wastage, high volumes of unaccountedfor-water, illegal connections, mismanagement of funds from water bills, nonreading of meters, and non-payment of water bills (Onjala, 2001). Under the arrangement, more water service providers including Water Companies, Community Water Projects, and more Private Individuals were facilitated to supply water unlike before when the government was the sole provider of water. By 2012, there were 122 registered WSPs, both public and private each linked to respective 8 regional WSBs, namely, Coast, Nairobi, Central, Rift Valley, Northern, Lake Victoria South, Lake Victoria North, and Tanathi through Service Provision Agreements (SPAs) and the number continued to grow (WASREB, 2010).

The paper argues that appropriate public private partnership led to improved water service provision in terms of access to water affordability, coverage, and quality and customer service in Kenya and reversed the poor performance ob- 
served before the water sector reforms in 2003 .

\section{Theoretical Framework}

The study is based on governance theory. The World Bank (Hopkins, 1991) defines governance as the exercise of political authority and the use of institutional resources to manage society's problems and affairs. Governance may also be seen to be concerned with steering actions of political authorities as they deliberately attempt to shape socio-economic structures and processes (Mayntz, 2004). As a theory, governance tackles the following critical concerns: Institutions and actors from within and beyond government; networks involving Public Private Partnerships (PPP) or with the collaboration of community organizations; the use of market mechanisms whereby market principles of competition serve to allocate resources while operating under government regulation and finally, through top-down methods that primarily involve governments and state bureaucracy, and mainly manifested in either one or a combination of policy, legal, and institutional frameworks (Gerry, 1998). In this context, water service provision is seen as a function of a combination of interactions from various institutional, community and individual actors as Service providers, financiers or regulators to the extent that the better the level of governance of the interactions, the better the quality of water service provision.

The theory argues that it is the responsibility of the government to provide water to its citizens in the course of which, interactions occur in various forms and scope between the government, the private sector and the public. The services can be provided either on the accord of the government or as a result of demands for their provision placed by the citizens. The quality of provision of water service is influenced by the nature of interaction between the government, the private sector, other service providers, and consumers of the services.

As a provider of public goods and services government of Kenya, through established institutions including the Ministry of Water and Irrigation (MWI), Local Authorities, National Water Conservation and Pipeline Corporation (NWC \& PC), and relevant regulatory agencies such as Water Services Regulatory Board (WSRB) and Water Resources Management Authority (WRMA) interact and partner with various stakeholders to supply quality water to the consumers under time considerations. For instance, a Water Service Provider (WSP) requires abstraction permit from WRMA and a Service Provision licence from WASRB. In the process of provision, it could seek funds for infrastructure development from NGOs, Government institutions, Community members. The WSPs providers which are able to navigate through the partnerships and interactions appropriately will be able to produce better services in terms of affordability, access, and customer service than those which have not engaged in successful public private partnerships.

The assumption is that more private sector involvement through public private partnership resulting from good governance shall lead to improvement in service delivery as measured in terms of increased access to quality and afford- 
able water through better management of interactions among the stakeholders.

\section{Methodology}

The study covered the Lake Victoria Basin, one of the five Drainage Basins which make up $59.2 \%$ of the total surface and $18.7 \%$ of ground water in Kenya. Other drainage basins are, Ewaso Ngiro, Rift Valley, Tana River and Athi River (Mogaka et al., 2006). Each of the Drainage Basins is served by their respective Water Service Boards (WSBs). Lake Victoria is served by two WSBs, Lake Victoria North and Lake Victoria South. This article however, concentrated on Lake Victoria South Water Service Board (LVWSB), the largest WSB in terms of population in Kenya at 6,868,876,000 people (WASREB, 2010).

In order to have a representative sample, seven (7) WSPs of the thirteen (13) registered WSPs under LVSWSB were identified using stratified random sampling method based on population being served and categorized into two strata: Public Limited Companies (PLCs) and registered Community water projects from the official register of WSPs maintained by Kenya Water Service Providers Association.

The PLCs were further stratified into Large, Medium and Small WSPs depending on the number of household connections. There were 3 WSPs in large, 1 in medium stratum and 3 in small stratum. The large PLCs stratum had between 10000-34999 connections and included: Kericho Water and Sanitation Company (KEWASCO) and Kisumu Water and Sanitation Company (KIWASCO) and Chemosit are among the large WSPs. The medium stratum had between 5000 9999 connections and had only South Nyanza Water and Sanitation Company (SNWSCO) in its rank. Siaya and Bondo Water and Sanitation Company (SIBO), Gusii Water and Sanitation Company (GWASSCO), and Migori, Kuria and Transmara Water and Sanitation Company (MIKUTRA) fell in the stratum of small WSPs having less than 50,000 connections. The registered community water projects included: Boya, Gulf, Ahono, Nyando, Mogombet and Nyasare. Through stratified random sampling, 2 large, 1 Medium, 1 Small PLCs and 3 registered Community Water Projects were selected for study.

The respondents were randomly selected from a sample of households drawn from a list of registered members per sampled WSP who had stayed within the area and used the existing WSP since 2003. A total of 288 respondents were identified as shown in Table 1. Due to homogeneity of household respondents in each stratum, the sample was sufficient to provide impression of the situation in each WSP.

The highest number of respondents was obtained from SNWSCO due to the fact that its two schemes, West Karachuonyo Community water Project in the rural set up and Homa Bay in the urban set up were combined with each contributing 28 and 32 respondents respectively. The number of respondents for Boya was higher than those from Nyasare despite having fewer household connections. Nyasare and MIKUTRA WSPs are both within Migori town and operate alongside each other but exhibited different characteristics. KIWASCO which 
Table 1. Showing the distribution of respondents per Water Service Provider (WSP).

\begin{tabular}{ccccc}
\hline NO. & Water Service Provider & Total Households Connection & Sample size & Percentage \\
\hline 1. & Chemosit & 8000 & 51 & $18 \%$ \\
2. & Mogombet & 923 & 29 & $10 \%$ \\
3. & KIWASCO & 13,500 & 56 & $19 \%$ \\
4. & BOYA & 600 & 30 & $10 \%$ \\
5. & South Nyanza & 3500 & 60 & $21 \%$ \\
6. & Mikutra & 1500 & 38 & $13 \%$ \\
7. & Nyasare & 900 & 24 & $8 \%$ \\
& Total & 28,923 & 288 & $100 \%$ \\
\hline
\end{tabular}

had the highest number of piped connections at 13,500 contributed 56 respondents.

The data from both secondary sources including literature review and document analysis, and key informant interviews from two senior officials of each WSP to explain the governance structure and the operations, were used to complement primary data collected from the household surveys. The study used structured questionnaires to interview each household head.

Each respondent was asked state: the distance from water source, the monthly expenditure on water, frequency of water supply interruptions, the colour and turbidity of water (physical quality of water), and time taken to restore water supply interruptions up to year 2004 (before the implementation of the reforms) and at the year 2012 (post reforms period). A change denoted the difference between those responding positively or negatively to a particular query for before 2004 and in 2012. For example, a positive difference between 2012 and 2004 connotes an improvement while a negative difference connotes deterioration in affordability, access, quality of water and customer service. The researcher relied on presentation of water bill and in its absence; the institutional memory of the household head as evidence. The underlying basis of the analysis was to establish the role that the governance has played in facilitating the provision of water. Were there deliberate action institutional stakeholders to influence or mitigate actions of other actors in terms of creating enabling environment or regulations? Did some WSPs gain more from the existing arrangements than others and why?

The data collected through questionnaire responses were coded, summarized into frequency tables, and analyzed using a computer package technique, Statistical Package for Social Scientists (SPSS). The report was presented using frequency tables to measure the central tendencies. To determine the changes, we used 2004 data as given by the household respondents in terms of affordability, access, quality of water and customer service.

\section{Results and Discussion}

The outcomes of the public-private partnerships in the provision of water services as obtained from the household data from the seven sampled WSPs were assessed in terms of customer service, quality of water, affordability of water, ac- 
cessibility to water, policy implications and presented in successive sections of this paper. In assessing the impact, the study appreciated the salient characteristics of each of the WSPs, which defined the extent of public private partnerships in each as shown in Table 2.

Table 2. Public-Private Partnerships in water enterprises in Kenya.

\begin{tabular}{|c|c|c|c|c|c|c|c|}
\hline \multirow{2}{*}{$\begin{array}{l}\text { CLASSIFICATION } \\
\text { OF WSPs } \\
\text { Organization/WSP }\end{array}$} & \multicolumn{4}{|c|}{ WATER COMPANIES } & \multicolumn{3}{|c|}{ COMMUNITY WATER PROJECTS } \\
\hline & CHEMOSIT & KIWASCO & SNWSCO & MIKUTRA & MOGOMBET & BOYA & NYASARE \\
\hline Responsibility & Public & Public & Public & Public & $\begin{array}{l}\text { Public \& } \\
\text { Private }\end{array}$ & $\begin{array}{l}\text { Public \& } \\
\text { Private }\end{array}$ & $\begin{array}{l}\text { Public \& } \\
\text { Private }\end{array}$ \\
\hline Form & $\begin{array}{c}\text { Management } \\
\text { Contract }\end{array}$ & $\begin{array}{l}\text { Management } \\
\text { Contract }\end{array}$ & $\begin{array}{l}\text { Management } \\
\text { Contract }\end{array}$ & $\begin{array}{c}\text { Management } \\
\text { Contract }\end{array}$ & Private & Private & Private \\
\hline Asset ownership & Public & Public & Public & Public & Private & Private & Private \\
\hline Tariff regulation & Public & Public & Public & Public & Public & Public & $\begin{array}{l}\text { Public \& } \\
\text { Private }\end{array}$ \\
\hline $\begin{array}{l}\text { Capital investment } \\
\text { in infrastructure }\end{array}$ & Public & Public & Public & Public & Private & Private & Private \\
\hline $\begin{array}{l}\text { Cost and quality } \\
\text { Monitoring }\end{array}$ & Public & Public & Public & Public & $\begin{array}{l}\text { Public \& } \\
\text { Private }\end{array}$ & $\begin{array}{l}\text { Public \& } \\
\text { Private }\end{array}$ & $\begin{array}{l}\text { Public \& } \\
\text { Private }\end{array}$ \\
\hline $\begin{array}{c}\text { Utility } \\
\text { management }\end{array}$ & $\begin{array}{c}\text { Public \& } \\
\text { Private }\end{array}$ & $\begin{array}{l}\text { Public \& } \\
\text { Private }\end{array}$ & $\begin{array}{l}\text { Public \& } \\
\text { Private }\end{array}$ & $\begin{array}{c}\text { Public \& } \\
\text { Private }\end{array}$ & Private & Private & Private \\
\hline $\begin{array}{l}\text { Operations and } \\
\text { Maintenance }\end{array}$ & $\begin{array}{l}\text { Public \& } \\
\text { Private }\end{array}$ & Private & $\begin{array}{l}\text { Public \& } \\
\text { Private }\end{array}$ & $\begin{array}{l}\text { Public \& } \\
\text { Private }\end{array}$ & Private & Private & Private \\
\hline Working capital & Public & Public & Public & Public & Private & Private & Private \\
\hline Commercial risk & Public & Public & Public & Public & Private & Private & Private \\
\hline $\begin{array}{c}\text { Popular } \\
\text { Participation }\end{array}$ & None & $\begin{array}{l}\text { AGM, BODs, } \\
\text { Retailers, Deleg. } \\
\text { line Managers }\end{array}$ & None & None & $\begin{array}{c}\text { AGM, } \\
\text { Management } \\
\text { Committee }\end{array}$ & $\begin{array}{c}\text { AGM, } \\
\text { Management } \\
\text { Committee }\end{array}$ & $\begin{array}{c}\text { AGM, } \\
\text { Management } \\
\text { Committee }\end{array}$ \\
\hline $\begin{array}{c}\text { Legal \& } \\
\text { Institutional } \\
\text { structure }\end{array}$ & $\begin{array}{c}\text { Service } \\
\text { Provision } \\
\text { Agreement }\end{array}$ & $\begin{array}{c}\text { Service } \\
\text { Provision } \\
\text { Agreement }\end{array}$ & $\begin{array}{c}\text { Service } \\
\text { Provision } \\
\text { Agreement }\end{array}$ & $\begin{array}{c}\text { Service } \\
\text { Provision } \\
\text { Agreement }\end{array}$ & $\begin{array}{c}\text { Service } \\
\text { Provision } \\
\text { Agreement }\end{array}$ & $\begin{array}{c}\text { Service } \\
\text { Provision } \\
\text { Agreement }\end{array}$ & $\begin{array}{l}\text { Service } \\
\text { Provision } \\
\text { Agreement }\end{array}$ \\
\hline $\begin{array}{c}\text { Management } \\
\text { of distribution } \\
\text { network }\end{array}$ & Direct & $\begin{array}{c}\text { Direct \& } \\
\text { Delegated }\end{array}$ & Direct & Direct & Direct & Direct & Direct \\
\hline Source of water & River & Lake & Lake & River & River & Bore-hole & $\begin{array}{c}\text { Natural } \\
\text { Springs \& } \\
\text { Bore hole }\end{array}$ \\
\hline $\begin{array}{c}\text { Geographical } \\
\text { coverage }\end{array}$ & Urban & Urban & Urban \& Rural & Urban & Rural & Rural & $\begin{array}{c}\text { Urban \& } \\
\text { Rural }\end{array}$ \\
\hline $\begin{array}{c}\text { Methods of } \\
\text { water delivery }\end{array}$ & $\begin{array}{c}\text { Indiv. } \\
\text { Connection \& } \\
\text { Water Kiosks }\end{array}$ & $\begin{array}{c}\text { Indiv. } \\
\text { Connection \& } \\
\text { Water Kiosks }\end{array}$ & $\begin{array}{c}\text { Indiv. } \\
\text { Connection \& } \\
\text { Water Kiosks }\end{array}$ & $\begin{array}{c}\text { Indiv. } \\
\text { Connection \& } \\
\text { Water Kiosks }\end{array}$ & $\begin{array}{c}\text { Indiv. } \\
\text { connection }\end{array}$ & $\begin{array}{c}\text { Indiv. } \\
\text { connection }\end{array}$ & $\begin{array}{c}\text { Indiv. } \\
\text { Connection \& } \\
\text { Water Kiosks }\end{array}$ \\
\hline $\begin{array}{l}\text { Institutional } \\
\text { Stakeholders }\end{array}$ & $\begin{array}{l}\text { WSRB, WRMA, } \\
\text { MWI, WSB, } \\
\text { EU, Nile Basin } \\
\text { Initiative }\end{array}$ & $\begin{array}{l}\text { WSRB, WRMA, } \\
\text { ADB, AFD, } \\
\text { WB, MWI, CC }\end{array}$ & $\begin{array}{l}\text { WSRB, WRMA, } \\
\text { MWI, CDF, } \\
\text { UNICEF, WSTF }\end{array}$ & $\begin{array}{l}\text { WSB, } \\
\text { WRMA, } \\
\text { MWI }\end{array}$ & $\begin{array}{l}\text { CDF, Church, } \\
\text { WSB, WRMA, } \\
\text { MWI }\end{array}$ & $\begin{array}{l}\text { CDF, NGOs, } \\
\text { UNICEF, } \\
\text { CHURCH, } \\
\text { WSB }\end{array}$ & $\begin{array}{l}\text { NGO, } \\
\text { WRMA, } \\
\text { WSB }\end{array}$ \\
\hline Contract duration & 5 Years & 5 Years & 5 Years & 5 Years & Indefinite & Indefinite & Indefinite \\
\hline Low & & & & & & & High \\
\hline \multicolumn{8}{|c|}{ Private Participation Autonomy } \\
\hline Source: Author's ow & compilation & & & & & & \\
\hline
\end{tabular}


Table 2 shows that there are mainly two categories of Public Private Partnerships in the WSPs under Lake Victoria South Water Board (LVSWB), Management Contracts and Private ventures. All the PLCs are management contracts while all the community water projects are private ventures. Whereas capital investments and Asset development for PLCs are handled by the Public, for the community water projects, it is done through public and private partnerships. The table further shows that all WSPs have adopted individual household connections and water kiosks as pro poor strategies to provide communal water supply at convenient places to individuals who do not have private household connections either due to long distance from water line, prohibitive connectivity fees or absence of title deeds as a proof ownership of the dwelling.

The involvement of popular participation was one of the key distinguishing features between public utilities and Community water projects. Whereas it was none existent in all the PLCs except KIWASCO, all the Community water projects embrace popular participation through Annual General Meetings and established management committees. Except for KIWASCO which offers both direct and delegated management of their distribution networks all other WSPs use direct management. The community water projects engaged directly more public private partnerships as exhibited in the higher number of partners, both local and international including churches, NGOs and government initiatives like Constituency Development Funds for both development of service infrastructure and improvement of water.

\section{Customer Service}

The fundamental question was whether the type of customer service provided varied with PPP arrangements of a WSP. This section discusses the following aspects of customer service delivery indicators: interruptions of water supply; length of time taken before supply interruption ws rectified; and customer care handling mechanisms.

\section{Interruptions of Water Supply}

The respondents were asked to state whether or not they had experienced interruption in their current water supply. In overall terms, of the 288 respondents, there were more cases of reported water supply interruptions in the public utility companies $(61 \%)$ than in the community water projects $(26 \%)$. This was attributed to the closer and regular water line patrols associated with the community water projects, hence faster reporting system and subsequent maintenance as reflected in their approaches to utility management, operations and maintenance of the distribution network.

The respondents were further asked to state how often in a month they had water supply interruptions in 2012 and at the beginning of the year 2004 when the Water Act 2002 was implemented and the results presented in Table 3. The frequency of water supply interruptions was higher in the utility companies than the community water projects. On average, the seven WSPs experienced water 
Table 3. Mean frequency of interruptions of water supply in days by WSP in a month.

\begin{tabular}{ccccc}
\hline \multirow{2}{*}{$\begin{array}{c}\text { Water Service } \\
\text { Provider }\end{array}$} & Water Interruptions & \multicolumn{2}{c}{ Interruptions other than Bill } & $\begin{array}{c}\text { Bill related } \\
\text { interruptions }\end{array}$ \\
\cline { 2 - 4 } & 2012 & 2012 & Before 2004 & 3.8 \\
\hline CHEMOSIT & 5.9 & 2.1 & 1.7 & 0.6 \\
KIWASCO & 4.3 & 4.3 & 4.9 & 3.4 \\
MIKUTRA & 5.9 & 2.5 & 2.3 & 3.0 \\
SNWSCO & 5.7 & 2.7 & 2.6 & 2.6 \\
MOGOMBET & 4.4 & 1.8 & 1.3 & 2.7 \\
BOYA & 4.9 & 2.2 & 2 & 4.0 \\
NYASARE & 6.8 & 2.8 & 2.3 & 2.5 \\
\hline OVERALL MEAN & 4.9 & 2.4 & 2.1 & \\
\hline
\end{tabular}

supply interruptions 4.9 times in a month reducing to 2.4 times a month when bill related interruptions were not taken into account.

Table 3 shows that the frequency of water supply interruptions has no direct relationships with the form of PPP. For example, frequency was highest at Nyasare Water Supply Association, a community water project with a mean of 6.8 times in a month, then followed by MIKUTRA and CHEMOSIT, public utility companies each at 5.9 times. Mogombet and Boya, Community water projects have mean frequencies of 4.4 and 4.9 , respectively. The mean frequency of water supply interruptions for all the seven WSPs per week increased from 2.1 times in 2004 to 4.9 times in 2012. Compared to the year 2004, the water companies have higher frequency increment than community water projects, to varying degrees. There was increased water supply interruptions most of which were bill related accounting for up to 2.5 times out of the 4.9 interruptions reported monthly in 2012 compared to the period up to the year 2004. This was an indication of increased revenue collection by the WSPs through disconnection of water supply to non complying consumers.

Whereas the extent to which a WSP dealt with reported interruptions indicated its preparedness to address customer complaints, dealing with unreported interruptions gauged the WSP's ability to carry out preventive maintenance by detecting and managing its service provision without being prompted to do so, thereby minimising inconvenience faced by the customers. The mean duration taken to address the water supply interruption was calculated and presented in Table 4.

Table 4 shows that on average, it took 17.7 days to restore water supply of the reported cases in the year before 2004 while it took a mean of 14.6 days as at December 2012. The waiting time before water supply is restored reduced in all the WSPs except MIKUTRA and Nyasare, an indication of improved customer service in terms of reduced waiting time due to increased public private partnerships. In both cases, the waiting time increased by 1.5 and 0.1 days, respectively. This was attributed to the fact that from less than 100 connections, 
Table 4. The mean duration taken before water service restoration WSPs.

\begin{tabular}{ccccccc}
\hline \multirow{2}{*}{$\begin{array}{c}\text { WATER } \\
\text { SERVICE }\end{array}$} & \multicolumn{3}{c}{ Reported interruption } & \multicolumn{3}{c}{ Unreported interruptions } \\
\cline { 2 - 7 } PROVIDER & $\begin{array}{c}\text { Now } \\
(\mathrm{x})\end{array}$ & $\begin{array}{c}\text { Before 2004 } \\
(\mathrm{y})\end{array}$ & $\begin{array}{c}\text { Difference } \\
(\mathrm{x}-\mathrm{y})\end{array}$ & $\begin{array}{c}\text { Now } \\
(\mathrm{q})\end{array}$ & $\begin{array}{c}\text { Before 2004 } \\
(\mathrm{r})\end{array}$ & $\begin{array}{c}\text { Difference } \\
(\mathrm{q}-\mathrm{r})\end{array}$ \\
\hline CHEMOSIT & 14.8 & 16.2 & -1.4 & 15.7 & 19.6 & -3.9 \\
KIWASCO & 13.5 & 17.4 & -3.9 & 16.4 & 20.4 & -4.0 \\
MIKUTRA & 19.5 & 18.04 & 1.5 & 20.9 & 23.4 & -2.5 \\
SNWSCO & 15.5 & 21.4 & -5.9 & 19.3 & 20.7 & -1.4 \\
MOGOMBET & 10.2 & 13.2 & -3.0 & 12.1 & 14.8 & -2.7 \\
BOYA & 12.1 & 14.6 & -2.5 & 12 & 12.7 & -0.7 \\
NYASARE & 15.2 & 15.1 & 0.1 & 17.4 & 20.3 & -2.9 \\
OVERALL MEAN & 14.6 & 17.7 & -3.1 & 16.9 & 20.2 & -3.3 \\
\hline
\end{tabular}

Nyasare water supply registered over 900 more household connections besides communal water stand pipes by the year 2012. Aroso, Onyalo and Posta areas to switched to Nyasare Water Supply Association for services. The greatest negative change was noted in SNWSCO in which waiting time reduced from an average of 21.4 days to 15.5 days.

In both reported and unreported cases, the water companies had registered greater degrees of improvement in terms of reduced number of days taken before water supply was restored than the community water projects. However, the restoration period of water supply after interruption was still shorter in community water supply projects than in the water companies. The general improvement was attributed to public private partnership through increased accountability and responsiveness that came with the water sector reforms on the water companies through the new institutions both regulatory and monitoring, namely WARMA and WASREB. The closer the supervision adopted by a WSP, the greater the reduction in waiting time before water supply was restored. The community water projects had engaged in close supervision for sustainability purposes hence shorter response period for both required preventive and corrective actions. As the public water supply got more commercialized, they developed closer monitoring and supervision of the water distribution networks through activities like regular line patrol and meter reading.

This is consistent with the findings of McGranahan that centralized systems put more emphasis on engineering solutions compared to the decentralized simple and innovative approaches, hence take longer to restore water supply interruption (Mcgranahan \& Kjellén, 2006).

\section{Quality of Water}

The quality of water was measured in terms of physical characteristics of water, colour and turbidity. The respondents were asked to state how many times each had coloured water from their household consumption connection. The as- 
sumption was that different WSPs would endeavour in various ways to supply quality water. The responses for the periods before and after the year 2004 were obtained and compared.

In terms of colour of water, $72.2 \%$ (208) of the respondents had observed coloured water from their current household connection while $27.8 \%$ had not in the year 2012. Compared to the period before 2004, 60.4\% (174) of the respondents had observed coloured water from their household connection while $39.6 \%$ had not hence giving impression that the situation was better in the period before the year 2004. There was hardly any difference between the periods before year 2004 and nine years later as showed in Table 5. However, since there was an overall reduction of coloured water despite increased population, we attributed this to presence of public private partnerships that had also taken care of the quality of water from alternative sources of water supply.

Table 5 shows that on average, only Chemosit and KIWASCO experienced increased frequency of coloured water being received by households by 0.4 and 0.8 days, respectively. The overall mean for all the WSPs reduced to 5.9 days as at January 2013 from 6.1 days in a month in the period before 2004. Nyasare recorded the greatest improvement during the same period. Contrary to the WSRB Impact report and assertion of Dagdeviren's finding in Ghana on provision of water by small scale providers (Dagdeviren \& Robertson, 2011), there was no evidence that water companies provided better quality water than community water projects. For example, Chemosit and Mogombet have same source of water supply yet the former had higher number of days (7.6) compared to the latter (5.1) when consumers from each WSP reported consuming coloured water.

\section{Affordability of Water}

Affordability was measured in terms of cost of water and the consumers' ability to pay. The respondents were asked to state how much they spent on water monthly, paid as connectivity fee, and the average monthly household income. The responses for the periods before and after 2004 were obtained and compared as shown in Table 6.

Table 5. Showing the mean frequency of coloured water by WSP in. no. of days.

\begin{tabular}{cccc}
\hline WSP & January $2013(\mathrm{x})$ & Before 2004 (y) & Difference $(\mathrm{x}-\mathrm{y})$ \\
\hline CHEMOSIT & 7.6 & 7.2 & 0.4 \\
KIWASCO & 6.3 & 5.5 & 0.8 \\
MIKUTRA & 5.3 & 5.6 & -0.3 \\
SNWSCO & 5.7 & 6.7 & -1 \\
MOGOMBET & 5.1 & 5.3 & -0.2 \\
BOYA & 3.6 & 3.65 & -0.05 \\
NYASARE & 5.2 & 6.6 & -1.4 \\
OVERALL MEAN & 5.9 & 6.1 & -0.2 \\
\hline
\end{tabular}


Table 6. Monthly expenditure versus income of households in 2012 and in 2004.

\begin{tabular}{|c|c|c|c|c|c|c|c|c|c|}
\hline \multirow[b]{2}{*}{$\begin{array}{c}\text { Water Service } \\
\text { Provider }\end{array}$} & \multicolumn{3}{|c|}{2012} & \multicolumn{3}{|c|}{ On or Before 2004} & \multicolumn{3}{|c|}{ Change to date } \\
\hline & $\begin{array}{c}\text { Mean } \\
\text { expend. } \\
\text { on water }\end{array}$ & $\begin{array}{l}\text { Mean } \\
\text { monthly } \\
\text { income }\end{array}$ & $\begin{array}{c}\% \text { of } \\
\text { income spent } \\
\text { on water }\end{array}$ & $\begin{array}{c}\text { Mean } \\
\text { expend. } \\
\text { on water }\end{array}$ & $\begin{array}{l}\text { Mean } \\
\text { monthly } \\
\text { income }\end{array}$ & $\begin{array}{c}\% \text { of } \\
\text { income spent } \\
\text { on water }\end{array}$ & $\begin{array}{l}\text { Expend. } \\
\text { On water }\end{array}$ & $\begin{array}{l}\text { Monthly } \\
\text { income }\end{array}$ & $\begin{array}{c}\% \text { of } \\
\text { income spent } \\
\text { on water }\end{array}$ \\
\hline CHEMOSIT & 462.13 & 16667.0 & 2.0 & 215.2 & 15333.6 & 1.4 & 246.91 & 1333.36 & 1.40 \\
\hline KIWASCO & 760.76 & 29167.25 & 2.6 & 253.59 & 23667.1 & 1.1 & 507.17 & 5500.11 & 1.50 \\
\hline MIKUTRA & 513.85 & 16417 & 3.1 & 285.29 & 13416.9 & 2.1 & 228.56 & 3000.06 & 1.00 \\
\hline SNWSCO & 510.51 & 15750.32 & 3.2 & 226.89 & 14750.3 & 1.5 & 283.62 & 1000.02 & 1.70 \\
\hline MOGOMBET & 395.4 & 12667.9 & 3.1 & 273.61 & 17083.7 & 1.6 & 121.79 & -4415.78 & 1.50 \\
\hline BOYA & 377.04 & 12916.9 & 2.9 & 235.24 & 10666.9 & 2.2 & 141.80 & 2250.02 & 0.70 \\
\hline NYASARE & 520.52 & 29167.25 & 1.8 & 315.32 & 15083.6 & 2.1 & 205.20 & 14083.61 & -0.30 \\
\hline OVERALL MEAN & 453.79 & 18167.03 & 2.5 & 243.58 & 16417 & 1.48 & 210.21 & 1750.03 & 1.02 \\
\hline
\end{tabular}

N/B. 1 Kenya Shillings (KShs) $\equiv 0.01$ US DOLLAR.

\subsection{The Cost of Water}

The cost of water in the seven WSPs was assessed before and after the year 2004 by considering ranges in the monthly water bills per household. The current water bills were verified by either checking the current individual monthly bill or with the individual bill listings at project office for the community water projects. However, the household heads were expected to give an approximation of what each spent in the year before 2004, as much as they could remember.

Contrary to our earlier expectations, none of the household heads had difficulty in recollecting, in approximate terms, what they used to pay in 2003. Over $70 \%$ of the respondents had at least a water bill for at least one month for the year. This was also corroborated with records at the offices of each WSP.

Table 6 shows that water was cheaper in the public water institutions than in the community water projects before 2004 due to government. On average, water was more expensive in community water projects before 2004 than in the public utilities. At Kshs 315.00 per month water was more expensive at Nyasare and cheapest at Chemosit (Kshs 215.20).

However, currently water is cheapest at Boya, a community water project at Kshs 377.04 per month and most expensive at KIWASCO at Kshs 760.76 per month followed by MIKUTRA at 513.85 as shown in Table 6. This was consistent with Dagdeviren's findings of privatization of water services in Ghana whereby a tariff rise of $105 \%$ was recorded between the years 2003 and 2010 (Dagdeviren \& Robertson, 2013). The latter charged higher rates to help sustain the cost of maintenance, facilitation of caretakers of the scheme (Dagdeviren \& Robertson, 2011). However, unlike Dagdeviren's finding it does not exclude the poor of the poorest. Our study revealed that the overall cost of water was cheaper in community water projects than in PLCs due to other related costs like standing charges on the consumers by PLCs. Generally, there was more public private participation in Community water projects than in PLCs, a confirmation 
of Whittington's observations of a well designed rural water supply (Nauges \& Whittington, 2009).

Water was therefore more affordable at community water projects than at water companies even where two WSPs happen to be in the same locality for example Nyasare and MIKUTRA in Migori, and Mogombet and Chemosit in Bomet due to more partners in form of NGOs that have partnered with the Community water projects.

\subsection{The Monthly Income of Households}

The section provides data on the income of individual households against their respective monthly expenditure on water in 2004 and the year 2012 to assess whether or not the proportion of household expenditure on water to that of income has changed. A positive change connoted improved economic status of consumers in the sense that they will be spending less proportion of their income on water. A negative change implied that, all other factors like inflation and cost of goods remaining constant, the consumers spent more proportion of their income on water with a direct impact on the consumer's cost of living.

Table 6 shows that the mean monthly income in 2012 was Kshs 18,163 while the expenditure on water is Kshs 453.79 compared to the monthly income in 2004 at Kshs 16,417.00 against mean expenditure on water of Kshs 243.58. This implies that households spent on water $2.5 \%$ of their income in the year 2012 compared to $1.48 \%$ in 2004 . The proportion of monthly income spent on water increased in the WSPs between 2004 and 2012 with exception of Nyasare Community Water Supply Association which recorded a decrease from $2.1 \%$ to $1.8 \%$. This was attributed to the social exclusion factor whereby only more privileged people were more likely to spend more money to connect water. KIWASCO, being in a city of a relatively higher income bracket, registered the highest mean monthly income.

Other than MIKUTRA, SNWSCO and Mogombet, the proportion of the expenditure on water of the monthly household income are all within the recommended level by UNDP as shown in Table 6 . The increased costs in water companies resulted from the withdrawal of subsidies by the government following the introduction of management contracts. In general terms, the increased proportion of individual household's expenditure on water was likely to have raised the cost of living for the consumers. This was still however within the acceptable limit of UNDP's recommended proportion of 3\% (Undp, 2006).

\section{Accessibility to Water}

The accessibility to water was measured using the distance from the water point, and the type of connectivity to water points. The results are shown in Table 7.

\section{Distance from Water Access Point}

The respondents were asked to state how far in metres they were from their respective water access points. The research established that of those who did not 
Table 7. The mean distance from water source by Water Service Provider.

\begin{tabular}{cccc}
\hline \multirow{2}{*}{ Water Service Provider } & \multicolumn{3}{c}{ Distance from water source in metres } \\
\cline { 2 - 4 } & 2012 & Before 2004 & Difference \\
\hline CHEMOSIT & 241.7 & 333.3 & -91.06 \\
KIWASCO & 188.3 & 218.3 & -30.0 \\
MIKUTRA & 221.7 & 258.3 & -36.6 \\
SNWSCO & 213.3 & 345 & -131.7 \\
MOGOMBET & 173.3 & 208.3 & -35.0 \\
BOYA & 211.7 & 273.3 & -61.6 \\
NYASARE & 195 & 361.7 & -166.7 \\
OVERALL MEAN & 211.7 & 290 & -78.3 \\
\hline
\end{tabular}

have piped water inside their respective houses, $86.5 \%$ had water within a range of $200 \mathrm{~m}$, while $6.5 \%$ (2) had accessed water at a distance of between $201-399$ $\mathrm{m}$. Only $0.9 \%$ accessed water at a distance of over $1 \mathrm{~km}$ away. These were from Chemosit and SNWSCO. This has further been confirmed by findings that PPP increased access in Busia within the same range of $1 \mathrm{~km}$ by $8 \%$ (Kombo, Kipkorir, \& Ekisa, 2014). This showed an improvement in access to water compared to the findings of Wagah which gave a figure of $77.1 \%$ for households in Kisumu with access to the nearest water point to within a distance of $200 \mathrm{~m}$ (Wagah, Onyango, \& Kibwage, 2010).

However, only $25.3 \%$ of the 288 respondents had piped water inside their respective households. KIWASCO had the highest number of respondents with piped water in the house at $9.0 \%$. The water companies registered more connectivity to individual houses than the community water projects courtesy of the existing water pipeline network.

The percentage for households with piped water, at $25.3 \%$, though an improvement from $24 \%$ found by Wagah (Wagah, Onyango, \& Kibwage, 2010), showed a downward trend from 31.9\% in 1989 to 30\% in 1999 (Kenya, 2004). The decline was attributed partly to the diminishing performance of the water schemes and partly due reduced operational loopholes. The proportion was even lower at $21.6 \%$ in a study conducted in Busia municipality (Kombo, Kipkorir, \& Ekisa, 2014). This was a confirmation that the reduction of distance from water access points resulted more from alternative water supply systems including other than formal household connections from the public utilities than from within same service providers.

Table 7 shows that at a mean distance of $290 \mathrm{~m}$ from the households, water sources were farther before 2004 compared to the current mean distance of 211.7 $\mathrm{m}$ in all the WSPs. In 2004, Nyasare Community water Supply Association had the highest mean distance from water sources at $361.7 \mathrm{~m}$ while Mogombet had the lowest mean distance from water source at $208.3 \mathrm{~m}$. There was noticeable reduction in distance from respective water sources in all the WSPs currently 
compared to the figures in 2004 with Nyasare recording the highest reduction of $166.7 \mathrm{~m}$ followed by SNWSCO at $133 \mathrm{~m}$ and Chemosit at $95 \mathrm{~m}$.

The least change was registered in KIWASCO at $30 \mathrm{~m}$, which was still very significant given the fact that KIWASCO served the city with high population density compared to the other areas served by the respective WSPs.

The reduction of the distance to water sources from the households was attributed to public private partnerships in the water service provision financing, hence increased collective water service points, kiosks and standpipes rather than through household connections which is consistent with the finding that water services improved more through private sector participation than if it were to remain under public sector management (Obosi, 2011).

Whereas Boya community project partnered with Sustainable Aid in Africa International (SANA), an NGO, to facilitate water supply in its area of operation, KIWASCO partnered with AFD to increase access to water in informal settlements of Nyalenda in Kisumu city while West Karachuonyo community water project, which was a scheme of SNWSCO, through Koguta community water project received facilitation from WSTF to extend water pipeline by 13 kilometres. This shows that the community water projects like the PLCs have distribution networks and pipelines which served customers by partnering with international NGOs and churches. This was consistent with findings of (Dagdeviren \& Robertson, 2011) in a study of urban CBOs partnering with International NGOs in Daresalaam. They found that the community water projects in Dares Salaam got financial and material resources to facilitate provision of water and that popular participation was critical for success of the operation of the Community based projects.

\section{Policy Implications}

The study exposed policy gaps in the regulation, management and operations as means to safe and reliable water provision to the people as a right. There was no clear policy governing public private partnership arrangements in Kenya. Each of the WSPs studied did not show consistency in terms of who was to be engaged and to what extent.

Whereas the community water projects exhibited characteristics of "unregulated" private ventures which engaged public and private institutions as and when convenient, the PLCs operated like government companies trading with the government on public goods. In both cases, the consumer had no benchmark expectations against which they could hold service providers accountable. There weren't deliberate and systematic efforts to hold the commercialized PLCs more accountable as expected of management contracts. In all the WSPs except KIWASCO, there wasn't competitive recruitment of key officers. The government applied bail out measures in terms of salaries of staff and payment of debts arbitrarily.

Secondly, there were notable weak linkages between the WSBs and the Community water projects. Whereas the WSBs were answerable to the national gov- 
ernments, the WSPs were accountable to the county governments hence lapses in the envisaged supervisory roles of WSPs by WSB due to conflict of roles between the national and county governments. It therefore called for the devolution from the Ministry responsible for water affairs of Water Supply, Sanitation and water regulation to the lowest appropriate level and autonomous Water Sector Institutions. This further called for further realignment of the functions to the County governments as opposed to the existing operations at national level. Even if it were to be maintained at the national level, relevant functions need to be delegated to the relevant County government offices to provide sufficient governance and autonomy of institutions for effective and efficient response.

The third policy implication was on management and ownership of assets. The good performance at the community WSPs was attributed to the participatory management approach which allowed closer supervision and monitoring of the operations. This was therefore a call for the government to facilitate communal participation in the governance of the Water Service provision institutions by strengthening self financing practices, provision of incentives for investors in the sector through PPPs arrangements and improving efficiency and coordination for optimal use of available funds. However, the private element in the PPPs, need not be restricted to corporate levels only but also to individual roles in kind or materials towards the realization of the expected goals. Furthermore, the impact of enhanced accountability through the separation of policy, regulation and operations in Water Service Provision as envisaged by the Water sector reforms can only be realized if the systems and policy guidelines are operational.

Finally, there is need for practical and flexible policy guidelines to support all WSPs irrespective of orientation to enhance water service provision. Although the community water projects combined both ownership and operations of the distribution network, their meagre and dwindling resource bases, could not afford the high capital required for a longer and bigger pipeline to take care of a larger population. It was therefore possible to entrust development and ownership of assets to County Authority, which could then lease particular lines to community organizations and private entities for closer supervision and management. For isolated areas, the small community water service providers were still preferable. The County Water infrastructure Development Authority could then invite private sector participation in development and financing. Under these integrated systems, viable water providers could be facilitated to make access to water service more affordable.

\section{Conclusion}

The exploratory study has established that the involvement of public private Partnerships has improved water services delivery to the extent that WSPs that have engaged more partnerships have recorded higher service delivery than those with fewer or no partnerships. The private participation autonomy is a key determinant of level of performance of WSPs. The public water utility compa- 
nies are still engaged in more government bureaucratic processes and therefore slow in striking strategic partners hence resulting in either slow improvement in or deterioration of water services in their respective areas of jurisdiction in partnerships. This varying latitude of interactions has resulted in relatively low cost of water, better customer service, and shorter distance from water access point in community water projects than in public water companies. The public private partnership, challenges notwithstanding, has proved to be a better alternative means of improving water supply services.

Secondly, community water projects, notwithstanding its loose organization and in the absence of a strong formalized and accountable state supported water service delivery mechanisms, present a better alternative water supply in Kenya. It also presents a better framework to engage PPP under the existing governance framework. The PLCs are too bureaucratic and are not open to participatory governance. The PPP arrangements in the management contracts are mainly of corporate nature especially in infrastructure development and most of the times involving bi-lateral and international donors.

However, the community water projects have adopted very flexible approaches including informal arrangements in terms of individual and community labour, goodwill, kind and resources in addition to the participation of NGOs, Churches and government agencies, like CDF and LATF. The partnerships are mainly for particular purposes and phases, at the risk of duplication which is seen as complementing the roles towards the supply of water to the needy population.

Finally, the geographical expanse of the Water companies has overwhelmed their capacity to manage effectively and efficiently the operations and offer enhanced quality services compared to the community services implying that if they were to operate at optimal level, the services could have been much better due to accruing economies of scale. For example, whereas each of the water companies operate at third their capacities in terms of population served, the community water projects are steadily bursting their initial capacities hence the compelling need to engage more partners to help keep pace with the demand for water. There is therefore, need for a more realistic and consolidated management and development of water infrastructure under County Water and Development Authority. The existing jurisdiction is too wide and not only prone to wastages but also trans-boundary conflicts.

\section{References}

Dagdeviren, H. (2008). Waiting for Miracles: The Commercialization of Urban Water Services in Zambia. Development and Change, 39, 101-121. https://doi.org/10.1111/j.1467-7660.2008.00470.x

Dagdeviren, H., \& Robertson, S. A. (2011). Access to Water in the Slums of Sub-Saharan Africa. Development Policy Review, 29, 485-505. https://doi.org/10.1111/j.1467-7679.2011.00543.x

Dagdeviren, H., \& Robertson, S. A. (2013). A Critical Assessment of the Incomplete Contracts Theory for Private Participation in Public Services: The Case of the Water Sector 
in Ghana. Cambridge Journal of Economics, 37, 1057-1075.

https://doi.org/10.1093/cje/bet007

Gerry, S. (1998). Governance as Theory: Five Propositions. International Social Science Journal, 50, 17-28. https://doi.org/10.1111/1468-2451.00106

Hopkins, M. (1991). Human Development Revisited: A New UNDP Report. World Development, 19, 1469-1473. https://doi.org/10.1016/0305-750X(91)90089-Z

Hulme, D. (1992). Enhancing Organizational Effectiveness in Developing Countries: The Training and Visit System Revisited. Public Administration and Development, 12, 433445. https://doi.org/10.1002/pad.4230120503

K'akumu, O. A. (2004). Privatization of the Urban Water Supply in Kenya: Policy Options for the Poor. Environment and Urbanization, 16, 213-222. https://doi.org/10.1177/095624780401600212

K'Akumu, O. A. (2007). Toward Effective Governance of Water Services in Kenya. Water Policy, 9, 529-543. https://doi.org/10.2166/wp.2007.025

Kenya (2004). Kenya Demographic and Health Survey 2003.

Kombo, P. N., Kipkorir, E. C., \& Ekisa, G. T. (2014). Public-Private Partnership Approach towards Enhancing Water Accessibility in Busia Municipality, Kenya. Water Practice \& Technology, 9, 353. https://doi.org/10.2166/wpt.2014.037

Mayntz, R. (2004). Governance Theory Als Fortentwickelte Steuerungstheorie (pp. 1120)? MPIfG Working Paper 04/1.

Mcgranahan, G., \& Kjellén, M. (2006). Informal Water Vendors and the Urban Poor (pp. 1-24). Human Settlements Discussion Paper Series 3. London: Inter- national Institute for Environment and Development.

Mogaka, H., Gichere, S., Davis, R., \& Hirji, R. (2006). Climate Variability and Water Resources Degradation in Kenya Improving Water Resources Development and Management. World Bank Working Paper Series, No. 69, Report No. 34854, World Bank, Washington DC.

Nauges, C., \& Whittington, D. (2009). Estimation of Water Demand in Developing Countries: An Overview. The World Bank Research Observer, 25, 263-294.

https://doi.org/10.1093/wbro/lkp016

Obosi, O. J. (2011). Public Private Partnerships in the Privatization of Water Service Delivery in Kenya. In U. Uhlig (Ed.), Current Issues of Water Management (Chapter 10). Rijeka: Intech.

Onjala, J. (2001). Water Pricing Options in Kenya: Cases of Mwea and West Kano Irrigation Schemes. CDR Working Papers.

Osborne, S. (2000). Introduction: Understanding Public-Private Partnerships in International Perspective: Globally Convergent or Nationally Divergent Phenomena? In S. Osborne (Ed.), Public-Private Partnerships: Theory and Practice in International Perspective (pp. 1-5). Abingdon-on-Thames: Taylor \& Francis. http://books.google.com/books?hl=en\&lr=\&id=DLQnVaKwVP0C\&pgis=1

Prasad, N. (2006). Privatisation Results: Private Sector Participation in Water Services after 15 Years. Development Policy Review, 24, 669-692. https://doi.org/10.1111/j.1467-7679.2006.00353.x

Schwartz, K. (2008). The New Public Management: The Future for Reforms in the African Water Supply and Sanitation Sector? Utilities Policy, 16, 49-58. https://doi.org/10.1016/j.jup.2007.07.001

Tati, G. (2005). Public-Private Partnership (PPP) and Water-Supply Provision in Urban Africa: The Experience of Congo-Brazzaville. Development in Practice, 15, 316-324. 
https://doi.org/10.1080/09614520500076068

Tochitskaya, I. (2007). Public Private Partnership. Minsk: German Economic Team in Belarus.

Undp, P. (2006). Human Development Report 2006. Beyond Scarcity: Power, Poverty and the Global Water Crisis (Vol. 28). New York: UNDP.

https://doi.org/10.18356/334c604b-en

Wagah, G. G., Onyango, G. M., \& Kibwage, J. K. (2010). Accessibility of Water Services in Kisumu Municipality, Kenya. Journal of Geography and Regional Planning, 2, 114-125. http://www.academicjournals.org/journal/JGRP/article-abstract/E9F373C39648

WASREB (2010). Impact: A Performance Review Report of Kenya's Water Services Sub-Sector. Nairobi. www.wasreb.go.ke

Submit or recommend next manuscript to SCIRP and we will provide best service for you:

Accepting pre-submission inquiries through Email, Facebook, LinkedIn, Twitter, etc. A wide selection of journals (inclusive of 9 subjects, more than 200 journals)

Providing 24-hour high-quality service

User-friendly online submission system

Fair and swift peer-review system

Efficient typesetting and proofreading procedure

Display of the result of downloads and visits, as well as the number of cited articles

Maximum dissemination of your research work

Submit your manuscript at: http://papersubmission.scirp.org/

Or contact ojps@scirp.org 